\title{
TAHAP PENGETAHUAN MAHASISWA UNIVERSITI AWAM (UA) NEGERI SELANGOR TERHADAP ILMU PERBANDINGAN AGAMA
}

\section{Aemy Elyani Mat Zain,Nazneen Binti Ismail, Norsaadah Din@ Mohamad Nasirudin dan Maryam Habibah Kamis}

Kolej Universiti Islam Antarabangsa Selangor. aemyelyani@kuis.edu.my

Diterima 24 Desember 2019 | Direview 27 Desember 2019| Diterbitkan 30 Desember 2019

\begin{abstract}
:
The field of Comparative Religion is getting more attention from most scholars in the world, including Malaysia. This is parallel with the nature of Malaysian community which is diverse. The more one knows of the knowledge in comparative religion, the more one is sensitive when interacting with the people of other religions. Hence, in the context of university students in Malaysia, how far is their level of knowledge in comparative religion? This study is going to analyse on the level of knowledge among public university students in Selangor towards the field of comparative religion. This is based on the respondents' demography which are gender, age, state originality, secondary education, department of study and the phase of study in university. The method employed is quantitative which used the Statistical Packages for the Social Science (SPSS) For Windows (version 22.0) and the findings are analysed descriptively. The result shows that, Min distribution is a high 4.04 Overall, it is shown that the majority of the public university students have certain knowledge in the field of comparative religion.
\end{abstract}

Keywords: Spi Knowledge level, student, public university in Selangor, comparative religion

\begin{abstract}
Abstrak:
Ilmu perbandingan agama merupakan satu bidang ilmu yang semakin mendapat tempat masyarakat dunia termasuk Malaysia. Ini menepati dengan sifat rakyat Malaysia yang majmuk. Semakin seseorang itu mengetahui tentang ilmu perbandingan agama, semakin dia peka apabila bergaul dan berinteraksi dengan penganut agama lain. Namun, dalam konteks mahasiswa universiti, bagaimana tahap pengetabuan mereka terhadap ilmu perbandingan agama. Maka, kajian ini dilakukan bagi menganalisis sejaub mana tahap pengetahuan mahasiswa
\end{abstract}




\begin{abstract}
universiti awam di Selangor terhadap ilmu perbandingan agama berdasarkan demografi mahasiswa dari segi jantina, umur, negeri asal, sekolah menengah terakhir, fakulti dan peringkat pengajian. Metod kajian yang dilakukan adalah kuantitatifyang menggunakan perisian Statistical Packages for the Social Science (SPSS) For Windows versi 22.0 dan seterusnya hasil kajian diburaikan secara deskriptif yang merangkumi nilai kekerapan dan peratusan. Hasil kajian menunjukkan bahawa tahap pengetahuan mahasiswa universiti awam negeri Selangor mengenai ilmu perbandingan agama mencapai taburan min yang tinggi iaitu 4.04. Ini jelas membuktikan bahawa mahasiswa universiti awam Selangor mempunyai pengetahuan yang jelas terhadap ilmu perbandingan agama.
\end{abstract}

Kata Kunci: Tahap pengetahuan, mahasiswa,universiti awam Selangor, perbandingan agama.

\title{
Pendahuluan
}

Istilah perbandingan agama, atau dalam bahasa Inggeris comparative religion, dan bahasa Arab pula disebut muqaranah al-adyan merupakan istilah yang berbeda tetapi mempunyai makna yang sama iaitu ilmu tentang perbedaan dan persamaan antara agama-agama). ${ }^{1}$ Perbandingan agama ialah kajian tentang agama-agama dan kemanusiaan bukan kajian tentang benda. ${ }^{2}$ Ilmu kajian agama adalah sebuah ilmu yang mandiri. Sifat perbahasan ilmu kajian agama juga adalah fleksibel yang membolehkannya menembusi disiplin-disiplin ilmu yang lain. ${ }^{3}$ Ilmu kajian agama juga adalah ilmu yang membahaskan berkenaan aspekaspek dalam agama seperti sejarah, kepercayaan, amalan dan akhlak.

Berdasarkan perbahasan di atas jelas menunjukkan ilmu perbandingan agama adalah satu bidang ilmu yang membahaskan hampir keseluruhan aspek dalam agama yang dilakukan secara perbandingan antara dua atau lebih agama. Ini jelas sekali menunjukkan ilmu perbandingan agama adalah ilmu yang terkandung di dalam satu-satu agama sama ada agama samawi (langit) mahupun

\footnotetext{
${ }^{1}$ Aemy Elyani Mat Zain, "Pendekatan Institut Kefahaman Islam Malaysia (IKIM) Dan Islamic Information and Services Foundation (IIS) Dalam Dialog Antara Agama Di Malaysia" (Universiti Kebangsaan Malaysia, 2015).

2 Taslim HM.Yasin, "Membangun Hubungan Antara Agama Mewujudkan Dialog Dan Kerjasama," Jurnal Substantia, 1, 12 (2011): 85-91.

${ }^{3}$ Wan Mohd Fazrul Azdi W.Razali, "Tema-Tema Ilmu Kajian Agama Dalam Muqaddimah Ibn Khaldun: Satu Perbahasan Ringkas,” 2017.
} 
agama ardi (bumi) secara perbandingan. ${ }^{4}$ Contohnya, perbandingan antara Islam-Kristian, perbandingan antara Hindu-Islam dan sebagainya.

\section{Metode}

Metod kajian yang digunakan dalam penyelidikan ini adalah bersifat kuantitatif yang menggunakan pendekatan berbentuk tinjauan atau disebut kajian pemerhatian (survey) melalui kaedah soal selidik. Kaedah mendapatkan data melalui soal selidik merupakan kaedah yang efisien dalam mekanisme kutipan data. ${ }^{5}$ Ini kerana penyelidik mengetahui maklumat yang diperlukan dan bagaimana mengukur pemboleh ubah yang dikenal pasti. Kaedah soal selidik digunakan untuk mendapatkan demografi mahasiswa dari segi jantina, umur, negeri asal, sekolah menengah terakhir, fakulti dan peringkat pengajian. Penggunaan instrumen soal selidik merupakan satu cara yang berkesan bagi mendapatkan maklumat daripada responden. ${ }^{6}$ Oleh itu, kajian ini secara keseluruhannya berbentuk kuantitatif dan data akan diukur secara statistik deskriptif seperti frekuensi dan peratusan sesuatu kumpulan data. Oleh itu penyelidik berpendapat kaedah ini sesuai dengan objektif kajian bagi mendapatkan maklumat yang lengkap dan tepat.

Lokasi kajian adalah di Selangor sahaja dan lebih khususnya di tiga universiti awam (UA) iaitu Universiti Kebangsaan Malaysia (UKM), Universiti Teknologi Mara (UiTM) dan Universiti Putra Malaysia (UPM). Sementara itu populasi responden pula terdiri daripada mahasiswa yang belajar di Universiti Awam di Selangor sahaja yang boleh dilihat daripada jadual populasi berikut:

JADUAL POPULASI MAHASISWA UNIVERSITI AWAM (UA) SELANGOR

\begin{tabular}{lc}
\hline Universiti Kebangsaan Malaysia (UKM) & 30,874 \\
Universiti Teknologi Malaysia (UiTM) & 165598 \\
Universiti Putra Malaysia (UPM) & 29,025
\end{tabular}

Sumber : Kementerian Pengajian Tinggi 2017

Kaedah pensampelan yang dilakukan ialah pensampelan secara rawak telah digunakan dalam menentukan responden bagi kajian. Teknik pensampelan rawak digunakan bagi memastikan pelbagai kategori mahasiswa

\footnotetext{
${ }^{4}$ Wan Mohd Fazrul Azdi W.Razali.

${ }^{5}$ Sekaran, Research Methods for Business A Skill-Building Approach, 4th ed. (New York: John Wiley \& Sons, 2003).

${ }^{6}$ Tuckman, Bruce W, Conducting Educational Research (San Diego, California: Harcourt Brace, 1994).
} 
diwakili daripada populasi sebenar kajian ini. Unit sampel dipilih secara rawak di Universiti Putra Malaysia (UPM), Universiti Teknologi Malaysia (UiTM) Shah Alam dan Universiti Kebangsaan Malaysia (UKM). Tujuan soal selidik ini diedarkan kepada responden secara rawak kerana sesuai dengan konteks Malaysia yang lazimnya rakyat Malaysia hidup secara majmuk tanpa meletakkan seseorang itu berada dalam bidang perbandingan agama atau luar daripada bidang ini. Maka, begitu juga mahasiswa beragama Islam dari pelbagai latarbelakang pendidikan hidup secara majmuk di institut pengajian masingmasing.

Dalam kajian ini, borang soal selidik sepenuhnya digunakan sebagai instrumen kajian utama. Ini dilakukan berlandaskan penelitian yang meletakkan soal selidik merupakan satu instrumen yang sering digunakan secara meluas dalam kajian kuantitatif. ${ }^{7}$ Bagi mengukur tahap pengetahuan mahasiswa universiti Awam (UA) di Selangor terhadap ilmu perbandingan agama, kajian menggunakan Skala Likert bermula daripada skala 1 (sangat tidak setuju) sehingga 5 (sangat setuju) bagi setiap item. Skala Likert digunakan kerana ia merupakan kaedah yang popular digunakan untuk mengumpul maklumat dalam tempoh yang singkat dan mudah untuk diurus, dipakai serta boleh dianalisis dengan berkesan. ${ }^{8}$

Seterusnya, dari sudut kesahan kajian yang merujuk kepada sejauh mana sesuatu ujian itu mengukur apa yang sepatutnya diukur. ${ }^{9}$ Ciri utama yang mesti ada dalam menentukan kesesuaian dan kebolehgunaan sesuatu instrumen adalah kesahan dan kebolehpercayaan. Kesahan instrumen merujuk kepada sejauh manakah suatu instrumen mengukur mengikut apa yang diukur. Dalam kajian ini, kaedah analisis secara empirikal dilakukan berpandukan kepada aspek-aspek berkaitan. ${ }^{10}$ Kesahan kandungan pula adalah satu proses untuk memastikan item-item yang digunakan dalam instrumen mewakili bidang pengetahuan yang hendak diukur. ${ }^{11}$ Bagi mendapatkan kesahan dan kebolehpercayaan setiap item, pengesahan pakar dan kajian rintis perlu

\footnotetext{
${ }^{7}$ John W.Creswell, Mixed Methods Research \& Mixed Methods Reader, 2008th ed. (T.tp: SAGE Publication, n.d.).

${ }^{8}$ Mohd Najib Abdul Ghafar, Reka Bentuk Tinjauan Soal Selidik Pendidikan (Skudai: Universiti Teknologi Malaysia, 2013).

${ }^{9}$ Gay \& Airasian, Educational Research: Competencies For Analysis And Applications (Boston: Florida International University, n.d.).

10 Azhar Ahmad, "Strategi Pembelajaran Dan Pengaturan Kendiri Pendidikan Islam Dan Penghayatan Akhlak Pelajar Sekolah Menengah” (Universiti Kebangsaan Malaysia, 2006).

${ }^{11}$ Wiersma, Research Methods In Education: An Introduction. (London: Allyn \& Bacon, 2010).
} 
dilakukan terlebih dahulu.

Untuk pusingan pertama, penyelidik membuat kajian terhadap tulisan sarjana yang berkaitan dengan perbandingan agama serta instrumen yang sedia ada. Selain itu, penyelidik juga mengadakan perjumpaan kumpulan penyelidik bagi membincangkan bentuk-bentuk konstruk yang perlu ada dalam setiap pemboleh ubah yang dikemukakan. Kemudian, penyelidik mula merangka item-item kajian bagi pemboleh ubah tersebut.

Instrumen yang mempunyai kesahan boleh diguna pakai kerana mengandungi semua ciri-ciri yang menerangkan aspek yang hendak diukur. Untuk mengukuhkan lagi kesahan bagi soal selidik ini, seramai dua orang pakar iaitu Dr Nurhanisah Senin dan Dr. Muhammad Yusof Marlon daripada Jabatan Dakwah dan Usuluddin, Kolej Universiti Islam Antarabangsa Selangor (KUIS) telah menyemak, memberi pandangan dan cadangan mengenai format, kandungan, bahasa, struktur ayat dan skala instrumen kajian ini. Pandangan dan cadangan daripada panel pakar telah diambil kira bagi memperbaiki instrumen kajian ini. Ini menjadi asas bagi instrumen kajian ini mempunyai kesahan kandungan yang baik.

Seterusnya, sebanyak 500 soal selidik telah diedarkan kepada responden kajian. Walau bagaimana pun, hanya 379 sahaja yang berjaya diperolehi daripada responden. Data yang dikumpulkan daripada 379 orang responden diproses dua kali untuk menentukan kebolehpercayaan dan kesahan instrumen yang digunakan. Seterusnya data dibersihkan untuk menyingkirkan sebarang outliers yang mengganggu. Jumlah sebenar data yang terkumpul untuk dianalisis setelah dibuang outliers termasuklah data yang lengkap diisi ialah 379 soal selidik. Semua data yang diperoleh diproses dan dianalisis menggunakan perisian komputer melalui Statistical Package For The Social Science (SPSS) For Windows (version 22.0). Dua jenis analisa digunakan iaitu analisis deskriptif (kekerapan, peratus, skor min). Kaedah penganalisisan data secara deskriptif telah digunakan untuk menjawab soalan kajian satu iaitu mengkaji tahap pengetahuan mahasiswa Universiti Awam (UA) Selangor terhadap ilmu perbandingan agama.

\section{Pembahasan}

\section{Demografi responden}

Bahagian ini menganalisis demografi responden yang mengandungi maklumat peribadi seperti jantina, umur, negeri asal, sekolah menengah terakhir, fakulti dan peringkat pengajian. Perbincangan analisis adalah berdasarkan nilai 
kekerapan dan peratusan.

Jadual 1 Taburan Responden berdasarkan jenis kelamin

\begin{tabular}{lll}
\hline Jenis Kelamin & Bilangan & Persen (\%) \\
\hline Lelaki & 82 & 21.6 \\
Perempuan & 297 & 78.4 \\
Jumlah & $\mathbf{3 7 9}$ & $\mathbf{1 0 0}$ \\
\hline
\end{tabular}

Sumber: Soal Selidik 2018

Proses pemilihan jumlah status jantina adalah untuk memudahkan terhadap data yang diperoleh. Selain itu, ia bertujuan untuk mempelbagaikan responden kerana pemikiran dan pemahaman antara lelaki dan perempuan sering kali berbeza.

Jadual 2 Taburan Bilangan dan Peratusan Responden Mengikut Umur

\begin{tabular}{lll}
\hline Umur & Bilangan & Peratus $\mathbf{( \% )}$ \\
\hline 20 - 25 tahun & 340 & 89.7 \\
26- 30 tahun & 23 & 6.1 \\
31-35 tahun & 8 & 2.1 \\
36- 40 tahun & 4 & 1.1 \\
41-45 tahun & 2 & 0.5 \\
46-50 tahun & 2 & 0.5 \\
Jumlah & $\mathbf{3 9 7}$ & $\mathbf{1 0 0 . 0}$ \\
\hline
\end{tabular}

Sumber: Soal Selidik 2018

Jadual 3 Taburan Bilangan dan Peratusan Responden Mengikut Negeri Asal

$\begin{array}{lll}\text { Negeri Asal } & \text { Bilangan } & \text { Peratus (\%) } \\ \text { Selangor } & 92 & 14.3 \\ \text { Kuala Lumpur } & 19 & 6.0 \\ \text { Johor } & 49 & 12.9 \\ \text { Kedah } & 29 & 7.7 \\ \text { Kelantan } & 44 & 11.6 \\ \text { Melaka } & 14 & 3.7\end{array}$




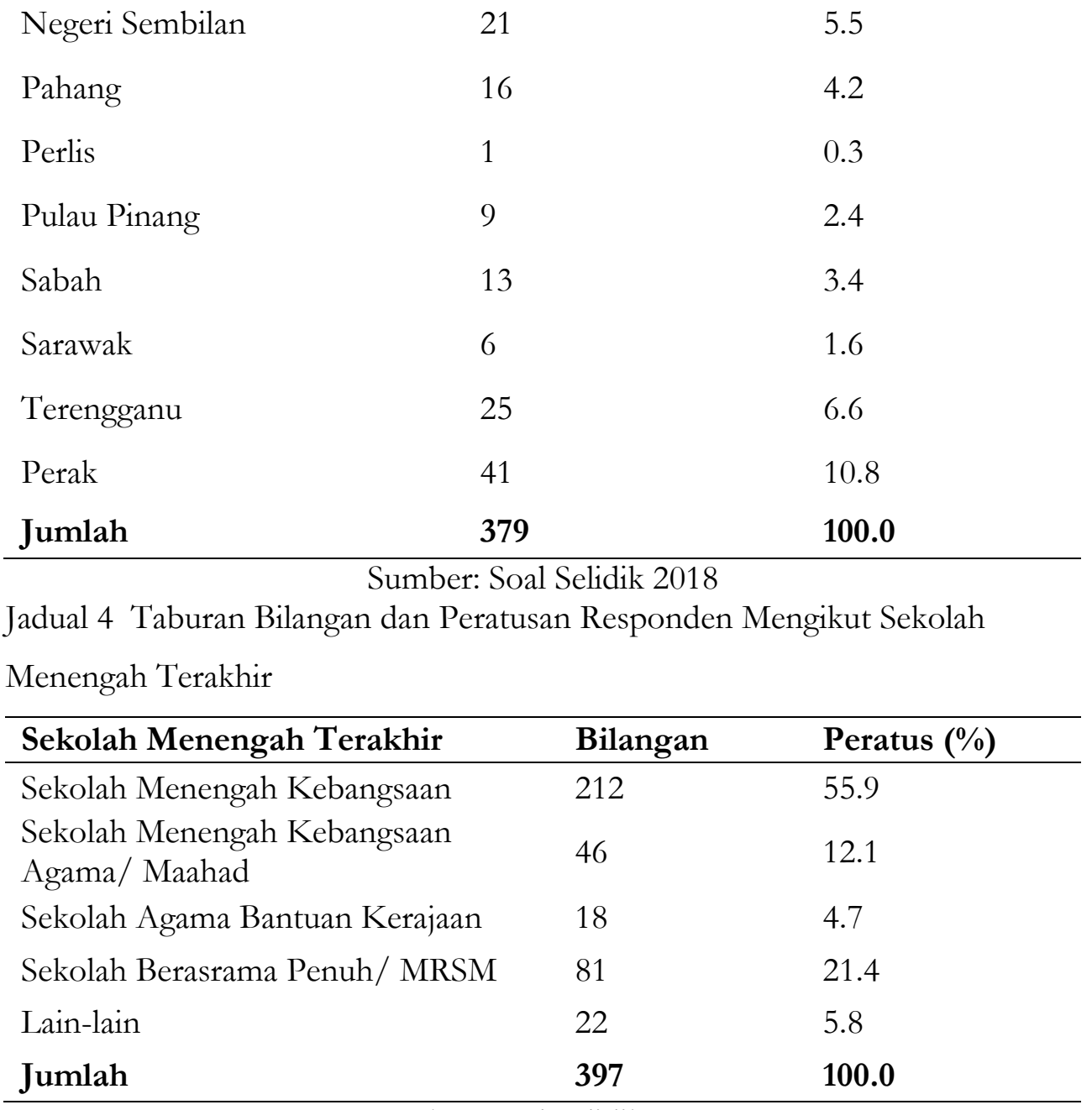

Sumber: Soal Selidik 2018

Jadual 5 Taburan Bilangan dan Peratusan Responden Mengikut Fakulti

\begin{tabular}{lll}
\hline Fakulti & Bilangan & Peratus (\%) \\
\hline Pengajian Islam & 41 & 10.8 \\
Sains Sosial & 51 & 13.5 \\
Sains Tulen & 116 & 30.6 \\
Pendidikan & 16 & 4.2
\end{tabular}




$\begin{array}{lll}\text { Ekonomi } & 38 & 10.0 \\ \text { Bahasa } & 37 & 9.8 \\ \text { Lain-lain } & 80 & 21.1 \\ \text { Jumlah } & \mathbf{3 9 7} & \mathbf{1 0 0 . 0}\end{array}$

Sumber: Soal Selidik 2018

Jadual 6 Taburan Bilangan dan Peratusan Responden Mengikut Peringkat Pengajian

\begin{tabular}{lll}
\hline Peringkat Pengajian & Bilangan & Peratus (\%) \\
\hline PhD & 18 & 4.7 \\
Sarjana & 54 & 14.2 \\
Sarjana Muda & 299 & 78.9 \\
Lain-lain & 8 & 2.1 \\
Jumlah & $\mathbf{3 9 7}$ & $\mathbf{1 0 0 . 0}$ \\
\hline
\end{tabular}

Sumber: Soal Selidik 2018

Jadual 7 Taburan Bilangan dan Peratusan Responden Mengikut Universiti

\begin{tabular}{lll}
\hline Universiti & Bilangan & Peratus (\%) \\
\hline UKM & 134 & 35.4 \\
UiTM & 118 & 31.1 \\
UPM & 127 & 33.5 \\
Jumlah & $\mathbf{3 9 7}$ & $\mathbf{1 0 0 . 0}$ \\
\hline
\end{tabular}

Sumber: Soal Selidik 2018

Analisis Kekerapan Demografi-Deskriptif

Berdasarkan jadual di atas membahaskan tentang demografi satu persatu mahasiswa di Universiti Awam (UA) Selangor. Didapati majoriti mahasiswa ini berumur 20 hingga 25 tahun iaitu seramai 340 orang (89.7\%) berbanding umur 40 tahun ke atas hanya beberapa orang saja $(0.5 \%)$. Ini bermakna mahasiswa dalam kajian ini adalah kelompok anak muda yang dalam pengajian ijazah sarjana muda iaitu sebanyak 299 orang $(78.9 \%)$ berbanding peringkat sarjana 
dan kedoktoran yang tidak mencapai 15\% ke atas.

Selain itu, dari sudut kekerapan bidang pengajian mereka, majoriti adalah berlatarbelakang Sains Tulen adalah seramai 116 orang (30.6\%) berbanding bidang Pendidikan hanya 16 orang (4.2\%) sahaja. Ini selari dengan sekolah terakhir mahasiswa sebelum melanjutkan pengajian ke menara gading, majoritinya dari sekolah menengah kebangsaan 212 orang $(55.9 \%)$ berbanding mahasiswa dari aliran pengajian Islam.

Analisis Deskriptif Tahap Pengetabuan Mahasiswa Universiti Awam (UA) Selangor terbadap Ilmu Perbandingan Agama

Analisis deskriptif dilakukan bagi menentukan tahap pengetahuan ilmu perbandingan agama dalam kalangan mahasiswa di Universiti Awam (UA) negeri Selangor. Untuk mengetahui tahap pengetahuan responden secara lebih terperinci, data telah diukur menggunakan peratusan. Secara umum, dapatan kajian menunjukkan bahawa mahasiswa mempunyai tahap pengetahuan tentang konsep perbandingan agama kerana mencapai nilai skor min tinggi iaitu min 4.04. Jadual berikut menunjukkan tahap pengetahuan mahasiswa secara terperinci.

Jadual 1 : Pengetahuan tentang Ilmu Perbandingan Agama

\begin{tabular}{clccccccc}
\hline Bil & \multicolumn{1}{c}{ Item } & STS & TS & TP & S & SS & Min & $\begin{array}{r}\text { Interp } \\
\text { retasi }\end{array}$ \\
\hline B01 & Saya & 4 & 15 & 65 & 185 & 110 & 4.01 & Tinggi \\
& $\begin{array}{l}\text { pernah } \\
\text { mende }\end{array}$ & $(1.1 \%)$ & $(4.0 \%)$ & $(17.2 \%)$ & $(48.8 \%)$ & $(29 \%)$ & & \\
& & & & & & & \\
& $\begin{array}{l}\text { ngar } \\
\text { mengenai }\end{array}$ & & & & & & & \\
& $\begin{array}{l}\text { ilmu } \\
\text { perbanding }\end{array}$ & & & & & & & \\
an agama & & & & & & & \\
B02 & $\begin{array}{l}\text { Ilmu } \\
\text { perbanding } \\
\text { an agama }\end{array}$ & $(0.8 \%)$ & $(0.5 \%)$ & $(12.9 \%$ & $(46.4 \%$ & $(39$. & & \\
& & & ) & ) & $3 \%)$ & &
\end{tabular}




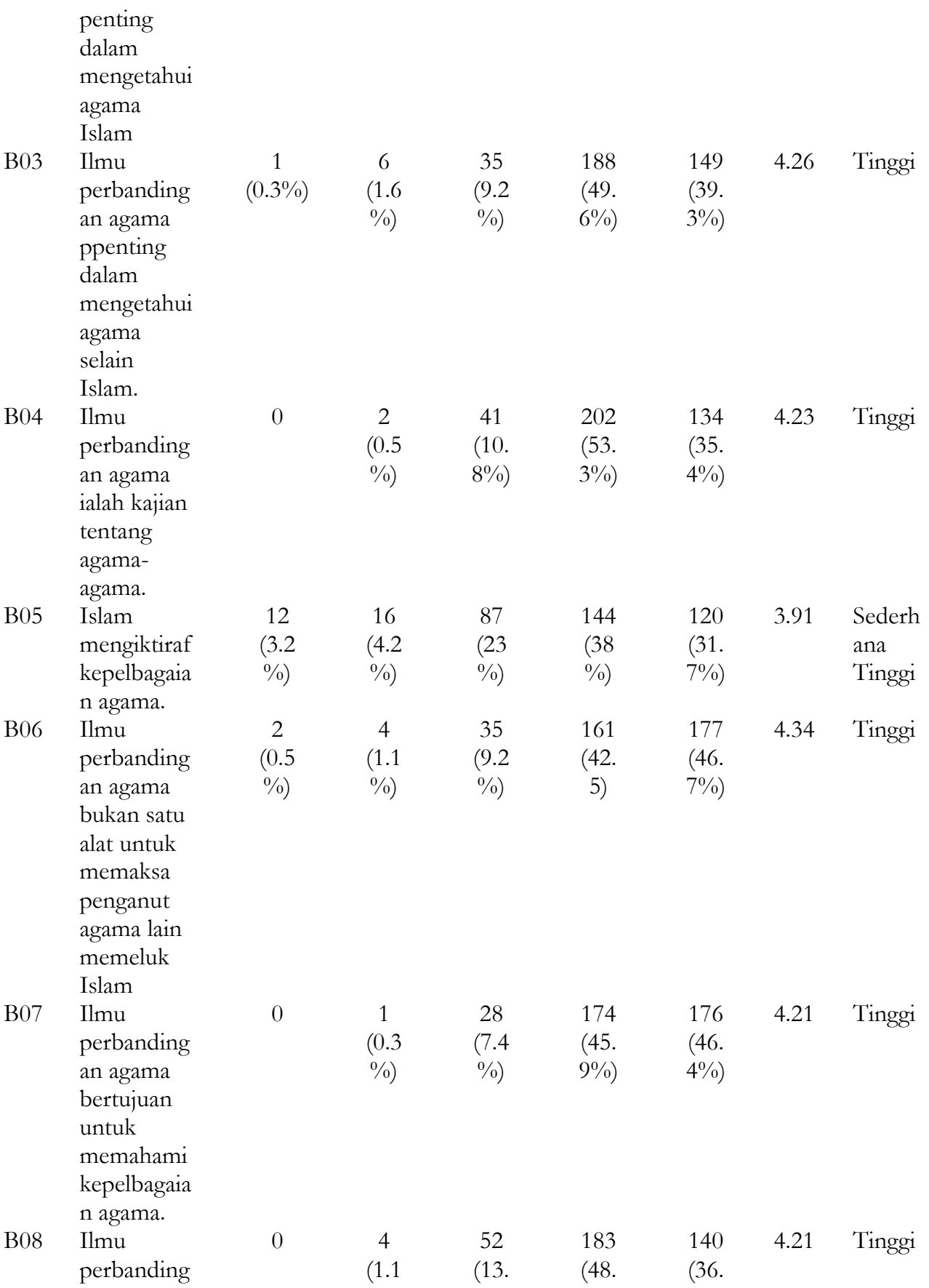


an agama merupakan alat untuk memahami agama sebagai fitrah manusia.

\section{B09 Sejarah} sesuatu agama boleh diketahui melalui ilmu perbanding an agama.

B10 Ilmu perbanding an agama

B11 Ilmu perbanding an agama tidak terhad kepada konsep ketuhanan sematamata.

B12 Persamaan dan perbezaan antara agama dapat diketahui melalui ilmu perbanding an agama.

\section{B13 Al-Quran} mementing kan ilmu perbanding
$\%)$

$7 \%$

$3 \%)$

$9 \%)$

$\begin{array}{ccccc}1 & 2 & 76 & 172 & 128 \\ (0.3 & (0.5 & (20 . & (45 . & (33 . \\ \%) & \%) & 1 \%) & 4 \%) & 8 \%)\end{array}$

4.12 Tinggi

(33.

$8 \%)$
0

0

5
$(1.3$
$0 \%)$

5
$(1.3$

$\%)$

4

(1.1

\%)
36

$(9.5$

$\%)$

92

(24.

3

162

(42.

$7 \%)$

172

(45.

$4 \%$ )

176

(46.

$4 \%$

111

(29

$\%)$
4.34 Tinggi

4.03 Tinggi 


\begin{tabular}{|c|c|c|c|c|c|c|c|c|}
\hline B14 & $\begin{array}{l}\text { an agama. } \\
\text { Rasulullah } \\
\text { menggunak } \\
\text { an } \\
\text { pendekatan } \\
\text { perbanding } \\
\text { an agama } \\
\text { dalam } \\
\text { dakwah } \\
\text { Baginda. }\end{array}$ & $\begin{array}{c}5 \\
(1.3 \\
\%)\end{array}$ & $\begin{array}{c}12 \\
(3.2 \\
\%)\end{array}$ & $\begin{array}{l}180 \\
(47 \\
\%)\end{array}$ & $\begin{array}{l}116 \\
(30 . \\
6 \%)\end{array}$ & $\begin{array}{c}66 \\
(17 . \\
4 \%)\end{array}$ & 3.60 & $\begin{array}{l}\text { Sederh } \\
\text { ana } \\
\text { Tinggi }\end{array}$ \\
\hline $\begin{array}{l}\text { BB1 } \\
5\end{array}$ & $\begin{array}{l}\text { Ilmuwan } \\
\text { Islam } \\
\text { mendahulu } \\
\text { i ilmuwan } \\
\text { barat } \\
\text { dalam ilmu } \\
\text { perbanding } \\
\text { an agama. }\end{array}$ & $\begin{array}{c}6 \\
(1.6 \\
\%)\end{array}$ & $\begin{array}{c}8 \\
(2.1 \\
\%)\end{array}$ & $\begin{array}{l}139 \\
(36 . \\
7 \%)\end{array}$ & $\begin{array}{l}134 \\
(35 . \\
7 \%)\end{array}$ & $\begin{array}{c}92 \\
(24 . \\
3 \%)\end{array}$ & 3.79 & $\begin{array}{l}\text { Sederh } \\
\text { ana } \\
\text { Tinggi }\end{array}$ \\
\hline B16 & $\begin{array}{l}\text { Ilmu } \\
\text { perbanding } \\
\text { an agama } \\
\text { sentiasa } \\
\text { mengalami } \\
\text { perkemban } \\
\text { gan melalui } \\
\text { pendekatan } \\
\text { yang } \\
\text { berbeza }\end{array}$ & $\begin{array}{c}1 \\
(0.3 \\
\%)\end{array}$ & $\begin{array}{c}4 \\
(1.1 \\
\%)\end{array}$ & $\begin{array}{l}103 \\
(27 . \\
2 \%)\end{array}$ & $\begin{array}{l}185 \\
(48 . \\
8 \%)\end{array}$ & $\begin{array}{c}86 \\
(22 . \\
7 \%)\end{array}$ & $\begin{array}{l}3.93 \\
\%\end{array}$ & $\begin{array}{l}\text { Sederh } \\
\text { ana } \\
\text { Tinggi }\end{array}$ \\
\hline B17 & $\begin{array}{l}\text { Dr. Zakir } \\
\text { Naik } \\
\text { adalah } \\
\text { tokoh } \\
\text { perbanding } \\
\text { an agama } \\
\text { kontempor } \\
\text { ari di } \\
\text { peringkat } \\
\text { antarabang } \\
\text { sa. }\end{array}$ & $\begin{array}{c}3 \\
(0.8 \\
\%)\end{array}$ & $\begin{array}{c}3 \\
(0.8 \\
\%)\end{array}$ & $\begin{array}{c}65 \\
(17 . \\
2 \%)\end{array}$ & $\begin{array}{l}151 \\
(39 . \\
8 \%)\end{array}$ & $\begin{array}{l}157 \\
(41 . \\
4 \%)\end{array}$ & 4.20 & Tinggi \\
\hline B18 & $\begin{array}{l}\text { Brother } \\
\text { Shah Kirit } \\
\text { adalah } \\
\text { tokoh } \\
\text { perbanding } \\
\text { an agama }\end{array}$ & $\begin{array}{c}2 \\
(0.5 \\
\%)\end{array}$ & $\begin{array}{c}8 \\
(2.1 \\
\%)\end{array}$ & $\begin{array}{l}230 \\
(60 . \\
7 \%)\end{array}$ & $\begin{array}{c}84 \\
(22 \\
2 \%)\end{array}$ & $\begin{array}{c}55 \\
(14 . \\
5 \%)\end{array}$ & 3.48 & $\begin{array}{l}\text { Sederh } \\
\text { ana } \\
\text { Tinggi }\end{array}$ \\
\hline
\end{tabular}


di Malaysia.

Sumber: Soal Selidik 2018

\section{Simpulan}

Melalui penelitian ini dapat disimpulkan bahwa:

Pengetahuan atau kejahilan seseorang itu terhadap sesuatu ilmu dapat dilihat secara zahirnya daripada penampilan dan sikapnya terhadap perkara tersebut. Begitu juga, pengetahuan mahasiswa berhubung ilmu perbandingan agama yang merupakan salah satu tradisi ilmu dalam Islam. Tahap pengetahuan ilmu perbandingan agama yang baik adalah asas dan dasar bagi mahasiswa dalam menilai perkara-perkara seperti kefahaman dan penghayatan mereka terhadap penganut agama lain. Ini kerana, pengetahuan ini dapat membentuk kerangka pemikiran seseorang itu dalam segala tindakan.

Pertama, dapatan kajian secara umum menunjukkan daripada skor min yang diperolehi; tahap pengetahuan asas mahasiswa terhadap ilmu perbandingan agama adalah memuaskan dan jelas. Ini boleh dilihat daripada hasil soal selidik daripada 18 item, sebanyak 12 item mencapai skor min yang tinggi. Sekaligus memberi makna bahawa ilmu asas perbandingan agama berada dalam pengetahuan mereka.

Namun, enam item yang tidak mencapai skor min tinggi kelihatan mempunyai sebab-sebab tersurat mahupun tersirat berlaku sebegitu. Sekalipun item B05 tidak mencapai skor min pengetahuan yang tinggi, namun bacaan hasil data empirikal membuktikan peratusan item B01 sehingga B12 (setuju dan sangat setuju) mencapai peratusan tinggi berbanding (sangat tidak setuju, tidak setuju dan tidak pasti). Ini menjelaskan tema pertama dalam ilmu perbandingan agama iaitu pengetahuan ilmu perbandingan agama dalam perspektif Islam berada dalam tahap yang memuaskan. Tambahan lagi, bacaan peratusan ini membawa maksud bahawa mahasiswa faham dan jelas akan perkara-perkara asas ilmu perbandingan agama dalam Islam seperti Islam mengiktiraf atau memperakui kepelbagaian agama di dunia ini. Ini amat seiring dengan ajaran agama Islam yang memperakui kewujudan agama, kepercayaan, budaya dan apa-apa yang lain daripada Islam. Agama Islam bukan bersifat anti kepada penganut agama lain bahkan meraikan mereka yang berbeza agama untuk hidup harmoni dan aman. Seperti mana petikan tafsir Pimpinan Ar-Rahman (JAKIM 2013) yang menegaskan kepelbagaian ini adalah sunatullah dan sebaikbaik kepelbagaian ini adalah mereka yang bertakwa kepada Nya. 
Seterusnya, bacaan bagi hasil data empirikal bagi item B13,B14, B15, dan B18 agak merungsingkan kerana peratusan (tidak pasti) itu mencapai nilai yang tinggi berbanding (setuju dan sangat setuju). Item mengenai wahyu alQuran (B13-49.3\%) dan dakwah Rasulullah SAW (B14-47.5\%) mencapai peratusan ketidakpastian tinggi. Kemungkinan mengenai ketidakpastian mahasiswa berlaku pada item B13 iaitu wahyu al-Quran disebabkan al-Quran terkandung segala bentuk panduan buat umat manusia khususnya umat Islam. Oleh yang demikian, ayat al-Quran yang menyentuh dan menekankan secara jelas mengenai ilmu perbandingan agama tidak difahami oleh mahasiswa melainkan mereka mengkaji bidang perbandingan agama atau berada dalam pengkhususan Pengajian Islam.

Jika ditelusuri terhadap kajian-kajian di kalangan sarjana Usuluddin dan Perbandingan Agama, mereka menegaskan bahawa kitab al-Quran menunjukkan peri penting ilmu perbandingan agama melalui dialog-dialog rasul dan nabi terdahulu dengan kaumnya serta pendekatan para nabi dan rasul dalam mendekati kaum mereka seperti pendekatan bikmah (bijaksana), mavi izat al-hasanah (nasihat yang baik) dan waja dilhum billati biya absan (berdebat dengan cara yang baik). ${ }^{12}$ Ini bertepatan lagi apabila menyatakan dalam kajiannya bahawa perbincangan mengenai agama-agama dan ideologi-ideologi dalam tradisi Islam terdahulu bermula dengan kitab al-Quran. Maka, ini tepat menjelaskan bahawa kitab al-Quran itu bukan sahaja mementingkan ilmu perbandingan agama, tetapi juga memulakan perbincangan ilmu ini. ${ }^{13}$

Begitu juga pada item B14 yang mengundang ketidakpastian mahasiswa iaitu berkenaan Rasulullah SAW yang menggunakan pendekatan ilmu perbandingan agama dalam dakwah baginda. Umumnya jelas kelihatan bahawa dakwah Rasulullah SAW melalui dakwah bil hal (perbuatan) iaitu keperibadian dan akhlak yang baginda tonjolkan. Namun, penelitian dan kajian sarjana turut membuktikan dakwah baginda SAW melalui ilmu perbandingan agama khususnya dalam sudut dialog antara agama. Dakwah baginda SAW melalui perbandingan agama jelas kelihatan melalui dialog baginda dengan pemukapemuka Kristian, Yahudi dan juga pemuka-pemuka dari kepercayaan lain

\footnotetext{
12 Aemy Elyani Mat Zain, "Pendekatan Institut Kefahaman Islam Malaysia (IKIM) Dan Islamic Information and Services Foundation (IIS) Dalam Dialog Antara Agama Di Malaysia." 13 Mohd Faizal Abdulkhir, "Metode Perbandingan Deskriptif Dalam Perbandingan Agama: Suatu Analisis Terhadap Metode al-Quran," QURANICA-International Journal of Quranic Research, $v, 1,2$ (2012): 131-45.
} 
seperti Majusi. ${ }^{14}$ Bahkan baginda berdakwah melalui perbandingan agama bukan sahaja melalui dialog tetapi juga melalui penulisan atau utusan surat kepada pemimpin-pemimpin lain seperti Hercules (Rum), Kisra (Parsi) dan Najashi (Ethiopia). ${ }^{15}$ Ini tepat sekali membuktikan bahawa Rasulullah SAW turut menggunakan pendekatan ilmu perbandingan agama dalam dakwah khususnya menerusi aspek ketuhanan.

Namun, apabila item B15 mempersoalkan tentang ilmuan Islam-Barat yang mendahului ilmu perbandingan agama. Bacaan data empirikal ini seolahnya lebih ke arah ketidakpastian mahasiswa akan meletakkan ilmuan Islam-Barat yang terawal dalam bidang ini. Umumnya, pengetahuan mengenai ilmuan Islam-Barat dalam ilmu perbandingan agama diketahui melalui pembacaan dan amat jarang diketahui melalui media massa. Ini kerana perbahasan ilmuan-ilmuan terdahulu dalam tradisi ilmu Islam mahupun Barat dapat diketahui melalui kajian-kajian sarjana kontemporari dalam bidang ini. Contoh yang jelas adalah kajian ilmiah yang menganalisis khusus salah seorang ilmuan dalam ilmu perbandingan agama terdahulu dan beliau menyenaraikan ilmuan-ilmuan dalam tradisi Islam yang telah menyumbang dalam ilmu perbandingan agama. ${ }^{16}$ Bahkan menurut dalam petikan makalahnya turut menegaskan bahawa ilmuan Islam mendahului ilmuan Barat dalam ilmu perbandingan agama berdasarkan pengiktirafan daripada sarjana kontemporari Barat sendiri seperti Adam Mez (1869-1917) dan Franz Rozenthal (19142003). ${ }^{17}$

Perkara terakhir iaitu pada item B18 yang mempersoalkan dari sudut kontemporari dakwah dalam ilmu perbandingan agama di Malaysia. Majoriti mahasiswa meletakkan ketidakpastian iaitu (60.7\%) dalam soal ini. Walaupun item hanya merujuk kepada pendakwah ilmu perbandingan agama dalam konteks Malaysia sahaja, ketidakpastian tetap berlaku kerana tokoh-tokoh pendakwah ini bukan selebriti yang dipromosikan dalam media massa. Bahkan tokoh-tokoh dalam perbandingan agama ini berkecimpung di bawah badan

\footnotetext{
${ }^{14}$ Faisal Ahmad Shah, Haziyah Hussin, Latifah Abdul Majid, Sabri Mohamad, Fadlan Mohd Othman, "Interfaith Dialogue: Approaches, Ethics and Issues," International Journal of Asian Social Science, 12, 3 (n.d.): 2455-64.

${ }^{15}$ Faisal Ahmad Shah, Haziyah Hussin, Latifah Abdul Majid, Sabri Mohamad, Fadlan Mohd Othman.

${ }^{16}$ Wan Haslan Khairuddin, “Tema Dan Metode Kritikan Rahmatullah Al-Kayranawi Terhadap Bible Berdasarkan Kitab Izhar al-Haq” (Universiti Kebangsaan Malaysia, 2018).

${ }^{17}$ Wan Mohd Fazrul Azdi W.Razali, "Tema-Tema Ilmu Kajian Agama Dalam Muqaddimah Ibn Khaldun: Satu Perbahasan Ringkas.”
} 
bukan kerajaan seperti Shah Kirit Kakulal Govindji, Firdaus Wong, Kamarudin Abdullah yang biasanya menggunakan ilmu perbandingan agama dalam mendekati dan berdialog dengan penganut bukan Islam. ${ }^{18}$ Hal ini sedikit sebanyak menyebabkan tahap pengetahuan mahasiswa dalam konteks dakwah kontemporari agak rendah.

Berdasarkan perbincangan di atas jelas menunjukkan setakat mana tahap pengetahuan mahasiswa universiti awam di Selangor mengenai ilmu perbandingan agama. Keseluruhan mahasiswa universiti awam mengetahui ilmu perbandingan agama dalam perkara-perkara yang umum dan asas. Ini dibuktikan daripada nilai min sebahagian besar item mencapai nilai yang tinggi. Namun, dua kategori item yang disebutkan sebelum ini tidak mencapai nilai min tinggi membuktikan perlunya didedahkan kepada mahasiswa universiti awam dan keseluruhan mengenai ilmu perbandingan agama dalam Islam itu sendiri. Ini bagi mengurangkan lagi sikap prejudis umat Islam khususnya generasi muda terhadap orang bukan Islam. Seterusnya, membuka ruang lagi kepada generasi muda ini peka dan jelas bagaimana bergaul serta berdialog dengan orang bukan Islam yang menepati syariah Islam.

Selain itu, umat Islam khususnya generasi muda Malaysia juga harus diberi ruang dan diberi pendedahan akan tokoh-tokoh perbandingan agama dalam Islam dan juga tokoh-tokoh perbandingan agama yang ada di Malaysia. Ini amat penting kerana melalui pengetahuan tentang setiap tokoh-tokoh Islam khususnya Malaysia dalam perbandingan agama dapat membantu umat Islam mendekati orang bukan Islam dengan cara yang betul dan kena pada tempatnya. Justeru, cadangan terakhir penulis seharusnya kursus ilmu perbandingan agama menjadi kursus pengajian teras dalam setiap universiti awam dan swasta. Dalam erti kata lain, ilmu ini tidak hanya diajarkan kepada mahasiswa dalam bidang Usuluddin dan Perbandingan Agama tetapi diperluaskan lagi menjadi kursus teras. Ini bagi melahirkan umat Islam yang bersifat terbuka dan wasatiyyah dalam bergaul kepada orang bukan Islam seperti mana tuntutan Islam. Bahkan, sebaiknya modul atau model dakwah menggunakan ilmu perbandingan agama perlu ditawarkan oleh penggubal dasar melalui kajian-kajian penyelidikan bagi memudahkan para pensyarah memandu mahasiswa cara yang selari dengan Islam apabila berkomunikasi dan berkawan dengan orang bukan Islam.

18 Aemy Elyani Mat Zain, "Pendekatan Institut Kefahaman Islam Malaysia (IKIM) Dan Islamic Information and Services Foundation (IIS) Dalam Dialog Antara Agama Di Malaysia." 


\section{Daftar Pustaka}

Aemy Elyani Mat Zain. "Pendekatan Institut Kefahaman Islam Malaysia (IKIM) Dan Islamic Information and Services Foundation (IIS) Dalam Dialog Antara Agama Di Malaysia." Universiti Kebangsaan Malaysia, 2015.

Azhar Ahmad. "Strategi Pembelajaran Dan Pengaturan Kendiri Pendidikan Islam Dan Penghayatan Akhlak Pelajar Sekolah Menengah.” Universiti Kebangsaan Malaysia, 2006.

Faisal Ahmad Shah, Haziyah Hussin, Latifah Abdul Majid, Sabri Mohamad, Fadlan Mohd Othman. "Interfaith Dialogue: Approaches, Ethics and Issues." International Journal of Asian Social Science, 12, 3 (n.d.): 2455-64.

Gay \& Airasian. Educational Research: Competencies For Analysis And Applications.

Boston: Florida International University, n.d.

John W.Creswell. Mixed Methods Research \& Mixed Methods Reader. 2008th ed. T.tp: SAGE Publication, n.d.

Mohd Faizal Abdulkhir. "Metode Perbandingan Deskriptif Dalam Perbandingan Agama: Suatu Analisis Terhadap Metode al-Quran." QURANICA-International Journal of Quranic Research,v, 1, 2 (2012): 13145.

Mohd Najib Abdul Ghafar. Reka Bentuk Tinjanan Soal Selidik Pendidikan. Skudai: Universiti Teknologi Malaysia, 2013.

Sekaran. Research Methods for Business A Skill-Building Approach. 4th ed. New York: John Wiley \& Sons, 2003.

Taslim HM.Yasin. "Membangun Hubungan Antara Agama Mewujudkan Dialog Dan Kerjasama." Jurnal Substantia, 1, 12 (2011): 85-91.

Tuckman, Bruce W. Conducting Educational Research. San Diego, California: Harcourt Brace, 1994.

Wan Haslan Khairuddin. "Tema Dan Metode Kritikan Rahmatullah AlKayranawi Terhadap Bible Berdasarkan Kitab Izhar al-Haq.” Universiti Kebangsaan Malaysia, 2018.

Wan Mohd Fazrul Azdi W.Razali. "Tema-Tema Ilmu Kajian Agama Dalam Muqaddimah Ibn Khaldun: Satu Perbahasan Ringkas," 2017.

Wiersma. Research Methods In Education: An Introduction. London: Allyn \& Bacon, 2010. 